\title{
"Can a Company be Bitchy?" Corporate (and Political and Scientific) Social Responsibility
}

\author{
Leigh E. Rich • Michael A. Ashby
}

Received: 22 March 2015 / Accepted: 4 May 2015 /Published online: 28 May 2015

(C) Journal of Bioethical Inquiry Pty Ltd. 2015

PHIL Oh, God, Lem. You're using science for no good. We took an oath we would try to do that less (Better Off Ted 2009a, "Bioshuffle," episode 109).

The American sitcom Better Off Ted (whose second and final season was released last fall on DVD) takes a stab at corporate ethics - and whether the concept can even exist. The premise of the caustically comedic program centers around a research and development department at "one of the largest corporations in America," the powerfully and preposterously named Veridian Dynamics (Better Off Ted 2009e, "Pilot," episode 101). Heading up the team is Ted Crisp, a handsome and driven but affable middle manager whom most everyone in the show desires either to be with or to be like. Phil and Lem are ingenious (though socially awkward) laboratory scientists, capable of making real most any idea the company throws at them-from cow-less "beef" and the world's smallest squirrel to weight-loss toothpaste and weaponized pumpkins. Ted's boss, Veronica Palmer,

\section{E. Rich $(\bowtie)$}

Department of Health Sciences (Public Health), Armstrong

State University, 11935 Abercorn Street, University Hall

154F, Savannah, GA 31419, USA

e-mail: leigh.rich@armstrong.edu

\section{A. Ashby}

Palliative Care Service, Royal Hobart Hospital, Tasmanian Health Service, and School of Medicine, Faculty of Health Sciences, University of Tasmania, 1st Floor, Peacock Building, Repatriation Centre, 90 Davey Street, Hobart TAS 7000, Australia

e-mail: michael.ashby@dhhs.tas.gov.au hair always drawn in a tight bun, is a no-nonsense and rather impassive self- and company-centered executive who is the personification of the corporation itself. And Linda Zwordling, the department's product testing manager, and Rose, Ted's eight-year-old daughter, provide a "fool's" perspective, acting as voices of conscience for the team.

Although funny and almost goofy at times, tapping into the frustration every "worker bee" likely experiences on a regular basis, the sitcom offers a platform for considering ethics in everyday life and what responsibilities employees and executives as well as companies (and other organizations) might have beyond one's job description or the corporate mission statement and strategic plan. In the pilot episode, Ted explains, "Is it wrong to invent a deadly pumpkin? Or an irritating chair that makes people work harder? Thing is, work's not about right and wrong. It's about success or failure" (Better Off Ted 2009e, "Pilot," episode 101). In this sense, Ted is a "company man," the darling of Veridian who has at least tasted the Kool-Aid of capitalistic corporate practice and is willing to pursue, although not without some thought, almost any product Veridian dreams up. That said, unlike other, minor characters in the show, he is not completely morally bereft, and he is liked by those both above and below him on the corporate ladder. He loves this favorable position and his job and is portrayed as a caring and competent boss and father, but - as the above quote indicates - he clearly has room to grow in his moral practice, particularly when it comes to achieving company objectives and his own ambitions. 
This can be seen in the pilot, which introduces viewers to the ensemble of characters as well as Veridian itself: fake promotional ads, included in most every episode and reminiscent of real commercials, satirically recast the company in the best possible light, ${ }^{1}$ and Ted eagerly responds to nearly all product requests his bosses make simply with, "We can do that." He does, however, hesitate when Veronica tells him:

$\begin{array}{ll}\text { VERONICA } & \text { We want to freeze Phil. } \\ \text { TED } & \text { Excuse me? } \\ \text { VERONICA } & \begin{array}{l}\text { Phil. The company wants to cryonically } \\ \text { freeze him. Just for a year, to see if it's } \\ \text { possible. We think it is. }\end{array} \\ \text { TED } & \text { You think it's possible? } \\ \text { VERONICA } & \text { Yes, Mr. Negative, we do. We have } \\ & \text { developed a chemical which allows us to } \\ & \text { rapidly freeze live animal tissue without it } \\ & \text { exploding. And, fingers crossed, we're } \\ & \text { ready for human testing. } \\ & \text { Your presentation sucks. And why Phil? } \\ \text { TED } & \text { Well, for PR reasons, they want an } \\ \text { VERONICA } & \text { employee. And in the unlikely event } \\ & \text { something goes wrong, well, there are } \\ \text { people here we would, you know, miss } & \text { more (Better Off Ted 2009e, "Pilot," } \\ & \text { episode 101, emphasis original). }\end{array}$

Although Ted and more vocally Linda and Lem (and initially Phil) express misgivings over the idea, they all stand by to witness history in the making. Phil is called a pioneer, going "someplace no one's ever gone before," and as he is being frozen declares: "What I do now I do for science. And so I do not ask for your concern. All I ask is for your respect. Respect as a scientist, respect as a friend. Respect as a man" (Better Off Ted 2009e, "Pilot," episode 101). The company, of course, hardly respects him or his sacrifice, unsure whether it will continue to pay his salary while frozen and deciding to fire him after he accidentally is thawed after three days and experiences disturbing and distracting side effects - an inability to

\footnotetext{
${ }^{1}$ For example, after the company is sued for a harmful product in the episode "Trust and Consequence," Veridian creates an advertisement with the following message: "Mistakes. We all make them. But sometimes mistakes lead to great discoveries. Mistakes are how we learn and grow, so we can do amazing things. When you think about it, shouldn't you be thanking $u s$ for making mistakes? Veridian Dynamics. We're sorry. You're welcome" (Better Off Ted 2009f, "Trust and Consequence," episode 110, emphasis original).
}

blink and a propensity to screech uncontrollably at inopportune times (Better Off Ted 2009c, "Heroes," episode 102). It is only Rose who clearly states that freezing Phil is wrong. While Veronica convinces Ted and Ted convinces Phil (though later regretting having "sold [him] a little too hard" on the idea), no one can convince Rose: "I like him the temperature he is," she says, admonishing her father that "it's wrong to ask Phil to do something you wouldn't do" (Better Off Ted 2009e, "Pilot," episode 101). Prior to the cryonic event, Linda pushes back as well but only so far as she is able while still keeping her job.

TED [asking honestly] So, freezing Phil?

LINDA [sardonically] You want to know about Phil? It's probably okay. If he can get past minus twenty degrees without his eyes bursting. That would be the first sign of trouble. This company is great, isn't it? Freezing its employees.

TED Uh, employee. We're only freezing one ... for now.

LINDA Do you know that they send us the phone bills for our nonwork-related calls? They don't charge us for 'em. They just want us to know that they know we're making 'em. Can a company be bitchy? (Better Off Ted 2009e, "Pilot," episode 101, emphasis original).

Thus, the moral distress that any of Veridian's employees voice is quickly squashed, whether due to fears of being on the company's bad side or simply looking stupid in front of coworkers, as in a later episode when Ted concocts a fake project to impress Linda and no one at Veridian will admit to not knowing what "Jabberwocky" actually is. ${ }^{2}$

\footnotetext{
$\overline{2}$ In this episode, Ted secretly reroutes company money to fund a rooftop garden that Linda has proposed, because she believes that Veridian - which has (falsely) publicly claimed it is "greening" its buildings worldwide - is finally putting its money where its PR mouth is. Word starts to spread about the elusive "Jabberwocky" initiative that more and more employees want to join solely because they think it will give them an advantage with their employer. The problem is, no one but Ted knows what "Jabberwocky" actually is (or isn't, as the case may be, because it doesn't really exist), and even as both executives and workers clamor to get on the team, no one will ask the simple question. Rather than appear ignorant, they pretend to know all about "Jabberwocky" and readily shame anyone who might inquire any further. Even the company and its executives eventually fast-track it and ship it to a branch in Japan, where no one there will ask about it either (Better Off Ted 2009d, “Jabberwocky," episode 112).
} 
Although Better Off Ted focuses on the corporate world, it is hard not to also see the similarities to medicine, science, and politics. In all of these realms there have been hegemonic mechanisms that emphasize ambition and discourage true moral dissent. One need only watch a handful of campaign ads (see, e.g., Craig and Rippere 2014; Dowling and Wichowsky 2015) or examine recent scandals in the pharmaceutical industry (e.g., Faunce, Townsend, and McEwan 2010; Plumridge and Burkitt 2014; etc.) to discern a Veridian sense of "winning at all costs." Even whistle-blower laws, designed specifically to protect those willing to expose misdeeds, don't prevent most claims from ending in "disappointment" and "despair" (Hallman 2014; Sharp 2012). And though much work has been done and some improvement made in enabling the expression of moral distress among nurses, in particular, as well as other members of inter-professional health care teams, "Jabberwocky"-like practical concerns persist (Jameton 1984, 2013; Zuzelo 2007; McLennan et al. 2014; Peter and Liaschenko 2013; Pendry 2007; Elpern, Covert, and Kleinpell 2005).

With the rise of bioethics in the twentieth century, the long history of moral philosophy, and the increasing emergence of professional codes of conduct, it is perhaps disheartening to ask how much progress we have made.

Ted claims that work (writ large) is not about "right and wrong" but, rather, "success or failure." The use of the conjunction "or" in the latter phrase intimates that success and failure are mutually exclusive. But is a company that pollutes the environment (e.g., Hiltzik 2014) or ensures that minimum wage is kept as low as possible (e.g., Patton 2012; Carpenter 2014), even if monetarily profitable, really successful? Are politicians, repeatedly reelected to office but with track records of legislation more friendly to big "donors" and special interests than individual citizens and the public good (e.g., Harris 2013; Friess and Keller 2014), deserving of praise as highly accomplished leaders? Is scientific and biomedical innovation that is carried out on the backs of vulnerable populations and takes advantage of gaps in national laws and toothless international policy true progress (see, e.g., Kumar 2014; Spielman 2015; Smith 2011; Brown et al. 2014)?

Veridian's stance is simple and unequivocal. When Ted wavers on whether to freeze Phil, Veronica merely tells him, "This is huge for us. You need to make it happen" (Better Off Ted 2009e, "Pilot," episode 101).
While real corporations, governments, and other organizations in today's day and age may not be freezing people, ${ }^{3}$ they certainly have experimented on themand not infrequently unbeknownst to the "participants." Oft-cited and gross examples include, of course, studies forced on the institutionalized, prisoners and prisoners of war, conscientious objectors, slaves, and minorities and the disenfranchised. ${ }^{4}$ The Nazis always rank high on this list as does the U.S. Public Health Service's forty-year Tuskegee syphilis study, but sadly these are just the tip of a very large and slow-moving iceberg. There also was Unit 731 in Japan (Kristof 1995); U.S. syphilis and gonorrhea research in Guatemala (Reverby 2012; U.S. Department of Health and Human Services n.d.); exploitation of African Americans by the medical and surgical professions before (and after) the U.S. Civil War (Gamble 1997; Skloot 2010); "isolated occurrences [of human experimentation] conducted on an ad hoc basis" during the Proceso regime in Argentina (Perechocky 2014, 548); the deliberate undertreatment of women with cervical cancer at a leading New Zealand hospital (Bismark and Morris 2014); and surreptitious experiments on patients, soldiers, and the public involving sterilization, malaria, radiation, cancer, and simulated germ warfare (e.g., Lombardo 2008; Kopp 2006), just to name a few. Harvard anesthesiologist Henry K. Beecher and English physician Maurice Pappworth also documented less obvious but a long list of similar examples half a century ago in a 1966 paper "Ethics and Clinical Research" and 1967 book Human Guinea Pigs: Experimentation on Man, respectively (Harkness, Lederer, and Wikler 2001). And, yet, other instances continue to be exposed today.

The papers in this issue of the Journal of Bioethical Inquiry touch upon the question of social responsibility and "trust" in health care, research, politics, and industry and consider the extent of progress made in the most fundamental aspects of bioethics, including respect for persons, dignity, beneficence, nonmaleficence, informed consent, dialogue, cultural competency, and justice (see, e.g., Haire 2015; Amzat 2015;

\footnotetext{
${ }^{3}$ Although several companies such as Alcor, the Cryonics Institute, and Google's new Calico (see, e.g., McNicoll 2013) offer "preservation" services following legal death for those wishing to do so and can afford it.

${ }^{4}$ Additionally, we don't touch upon here, but would be remiss to ignore, the use of nonhuman animals in experimentation, particularly in industry for nonessential products and in science and medicine where alternatives exist.
} 
McGrath, Rawson, and Adidi 2015). More than merely uncovering lingering areas of concern, several of the papers also propose clear directions for solutions.

Offering tangible next steps in both medicine and the law, Zara Bending, in "Reconceptualising the DoctorPatient Relationship: Recognising the Role of Trust in Contemporary Health Care," reexamines the contractual (and increasingly commercial) basis of the clinical exchange and demonstrates that neither this approach nor the less frequently advocated fiduciary model (which still "reinforce[s] the ascendency of physicians") "encapsulates the true nature of the contemporary doctorpatient relationship" (2015, \3 under "Introduction"). Instead, after examining (1) the risks of conflicts of interest in health care and examples from the "therapy-research nexus," (2) ties between providers and the pharmaceutical industry, and (3) the ongoing aftermath of the 1998 Wakefield et al. Lancet article that incorrectly advanced a causal link between the MMR vaccine and autism, Bending proposes an alternative model rooted in trust and underscores that "any characterisation of the relationship must acknowledge the power imbalance between parties (that is, to recognise patient vulnerability) while promoting patient autonomy and informed decision-making" (2015, \3 under "Introduction").

Such an approach is essential, within the health care encounter and beyond, as several of the other papers make clear. In a "Critical Perspectives" piece by John Kleinsman and Sue Buckley (2015), for example, the authors address ethical concerns in research conducted by social media giant Facebook that was published in a 2014 issue of the Proceedings of the National Academy of Sciences. The original study involved manipulating the "News Feeds" of "almost 700,000 randomly selected Facebook users," who were never informed that they were participants,

in order to assess whether their emotional states, as measured by their posting behaviours, were affected by the emotional expressions of others. In one group, exposure to friends' positive emotional content in their News Feeds was reduced; in another group, exposure to friends' negative emotional content was reduced. The effect on the participants was then measured by examining the emotionality of their status updates (Kleinsman and Buckley 2015, $₫ 3$, emphasis original).
The Facebook researchers, in defense of the study and its design but taken to task by Kleinsman and Buckley, "stated that they used word-counting software, which meant that original posts were not viewed by [them]"; that this "was consistent with Facebook's Data Use Policy to which all users agree"; and, later, that "the experiment was conducted by Facebook for internal purposes" (Kleinsman and Buckley 2015, ๆ4). While many today-particularly young people who have never known a pre-Internet world - might not bat an eye about a seemingly innocuous experiment and companies might invoke a caveat emptor claim that users must "read and accept" terms of service, there are echoes of similar disingenuous justifications that have enabled deceit and discrepancies in treatment in exchange for "free" care.

The same cautions can be made with regard to "free information." In "Drug Familiarization and Therapeutic Misconception Via Direct-to-Consumer Information," Jean-Christophe Bélisle-Pipon and Bryn WilliamsJones (2015) examine governmental policies that exist in most countries that limit direct-to-consumer advertising (DTCA) of pharmaceutical drugs. While much has been written about the risks of DTCA in the United States and New Zealand (the only two countries that currently allow DTCA), less attention has been given to supposed safeguards elsewhere that restrict DTCA but often allow direct-to-consumer information (DTCI). Using Canada's framework and Eli Lilly's DTCI campaign "40over40" that focuses on erectile dysfunction, Bélisle-Pipon and Williams-Jones reveal not only the surreptitious means used by the pharmaceutical industry to subliminally sway information-seekers to prefer their product over other brands and other forms of treatment but also how the regulations themselves make vested interests less transparent:

[A]s recommended by [Advertising Standards Canada's] guidelines (i.e., separating disease information and the name of the drug or manufacturer), the sponsor's identity in the ED campaign is not at all obvious. Viewers of the website need to be attentive and look under the "Privacy Statement," "Terms and Conditions," "Disclaimer," "Copyright," or "Accessibility" sections at the bottom of the page, which are in the smallest font and thus the least noticeable content on the website. The issue is that the campaign is an industry- and not a government-sponsored public 
health awareness or information activity. Providing clear details about the sponsor's identity would likely help. [...] Yet, the very policies that were supposedly designed to protect the public from potentially manipulative DTCA in fact discourage or even prohibit industry sponsors from being transparent about their identity, with the result that it may be very difficult to distinguish between an industry-sponsored DTCI marketing campaign and a government-sponsored public health campaign (Bélisle-Pipon and WilliamsJones 2015, \5 under “An Example of Direct-toConsumer Information in Action," emphasis original).

Thus, they argue that DTCI is a form of direct-toconsumer indirect advertising and that regulatory bodies (and other governmental and professional organizations) should reexamine policies and begin to address DTCI campaigns as such.

Along similar lines, Rebecca Julia Cook investigates "Off-Label Drug Use as a Consent and Health Regulation Issue in New Zealand," underscoring how "current law provides medical practitioners with very wide discretionary power to prescribe off-label, without providing clarification for what is required of the practitioner in exercising his or her discretion" (2015, ๆ2 under "Introduction"). She argues that while the risks associated with off-label prescribing increase - such as "practitioners and patients being misled when relying on insufficient research supporting a particular use"; "adverse drug reactions and interactions"; and the application of drugs that "may later be shown to be unsafe and ineffective, which can have overwhelming consequences for public health" - "the regulation and liability of medical practitioners remains unchanged" (Cook 2015, \2 under “Introduction”). Like Bending, however, Cook proposes concrete suggestions for how to amend current law.

Legal loopholes also exist in the United States' new Patient Protection and Affordable Care Act, which mandates U.S. citizens "to have minimum essential [health] insurance coverage" (Galarneau 2015, under "Abstract") in an attempt to close the uninsured gap, reduce the ever-growing costs of health care, and improve health outcomes for all. Members of health care sharing ministries (HCSMs), however, are exempt from the mandate, as Charlene Galarneau (2015) discusses. Many people in the United States likely are unaware of the exemption's existence or how it came about"largely the product of legislative efforts by two Senate committees [...] and of lobbying efforts by the Alliance [of Health Care Sharing Ministries] and its supporters" (2015, -3 under "The ACA Exemption of HCSM Members") - and Galarneau expresses concern that HCSM membership (1) doesn't provide an equivalent form of health coverage (e.g., many health care "needs related to preexisting conditions are wholly or partially ineligible"); (2) may be revoked if members "have certain medical conditions" (e.g., "pregnancy while unmarried," "addiction to tobacco, alcohol, or other drugs and any illness or injury related to sex outside of 'traditional Christian marriage,' such as sexually transmitted infections"); and (3) undermines the primary policy goals of the law (Galarneau 2015, $\uparrow 1$ and $\uparrow 11$ under "Ineligible Needs"). For example, HCSM members are required to first seek out and use funding from other sources before requesting assistance from their ministry, essentially thus enabling them to "reap many of the benefits of the health care system without the corresponding responsibilities for adequate insurance coverage or for the shared responsibility penalty, thus constituting an unjust distribution of benefits and burdens" (Galarneau 2015, \1 under "Competing Principles? Justice and Religious Liberty," emphasis original).

Within medicine itself, there are also issues concerning how we classify and frame suffering, how we interact with patients who may differ from us, and how we publicly discuss and debate bioethical matters of importance.

For instance, Tamara Kayali Browne in "Is Premenstrual Dysphoric Disorder Really a Disorder?" (2015) argues that PMDD should not be categorized as a disease in the Diagnostic and Statistical Manual of Mental Disorders and the International Statistical Classification of Diseases and Related Health Problems, as doing so "pathologises understandable anger/distress," "ignore[s] the now accepted role that one's environment and psychology play in illness development, as well as arguments concerning the social construction of mental illness," and "label[s] women as mentally ill." Rather, she suggests that "the way to address this problem is to change societal attitudes towards women's suffering" (Browne 2015, under "Abstract").

Similarly, Cressida J. Heyes and Angela Thachuk (2015) analyze the differences in practice between "knowing-that" and "knowing-how" with regard to 
primary health care providers' cultural competency in the clinical encounter with queer women patients. Interviewing both patients and providers in Halifax, Nova Scotia, the researchers found that

despite verbal claims to the contrary many providers continue to assume that all their patients are serially monogamously, heterosexually active, having non-commercial, vanilla sex. [...] Not infrequently, in such circumstances many providers revert to $[\ldots]$ novice behaviors - trying to remember the right terminology or rules to follow in future interactions (and retrospectively going over the course of earlier interactions with the patient to see if there were instances in which they may have made mistakes or violated the rules). In such cases, the patient is often inadvertently reduced to an object the practitioner must correctly "identify and categorize." [...] Like the expert pilot, whose performance actually worsens when asked to follow the guidelines or formal rules, the practitioner's self-evaluation and reversion to novicelike behaviors inhibits engaging the practical skills of the involved performer (Heyes and Thachuk 2015, ๆ1-\$2 under "Critique of Practice").

And Bertha Alvarez Manninen in "Mutual Scorn Within the Abortion Debate" (2015) unpacks the entrenched perspectives of "pro-life" and "pro-choice" activists and demonstrates how the increasingly "othering" rhetorical structure of political debate leads to unnecessarily adversarial positions and prevents real dialogue and thus real avenues toward common goals. As she notes: "One can be in favor of abortion choice, both morally and legally, and still maintain that fetal life is worthy of profound respect and care given its status as nascent human life" (Manninen 2015, $\$ 10$ under "Steps Toward Convergence"); likewise, one can advocate for fetal life and work toward preventing unwanted pregnancies and abortion while recognizing women's autonomy and bodily integrity. Unfortunately, parties on both sides instead engage in forms of derisive and divisive debate that encourages alienation and dehumanization.

What seems to be in rare existence in many of the issues raised by the papers herein is trust-honesty about intentions and limitations, transparency in attitudes and actions, and authentic care and respect for one another. A fundamental virtue of moral character, Claudia Slegers and colleagues (2015) also discovered that trustworthiness is essential for good science, as it underpins why people participate in research:

Our findings confirm how critical trust is to the conduct of research and how necessary it is that research institutions do not act in ways that betray trust. Indeed, what [our] discussion suggests is that it is not respect for autonomy and its enactment as the practice of obtaining informed consent or refusal that should be regarded as the cornerstone of contemporary research ethics. Rather, it is the trust that the public retains in its institutions and the people who work in them that enables research to proceed with what is frequently less than full understanding on the part of participants (Slegers et al. 2015, $\mid 3$ under "Trust," emphasis added).

Even Ted in Better Off Ted talks about trust. "Once you have that trust," he says, "you know someone will always have your back. [...] But the most important thing is the trust the public has in our products. That's why many of our products never get past the testing phase" (Better Off Ted 2009f, "Trust and Consequence," episode 110).

Slegers et al., however, found that "[t]here is widespread public distrust of research sponsored or conducted by private companies. Pharmaceutical companies, in particular, were repeatedly singled out by participants, almost without exception on the basis that a drug company's over-riding motivation was to make a profit" $(2015, \boldsymbol{\Upsilon} \mathbf{9})$. And it's not just corporations. Science and scientists have many times deemed the "pioneering" aspect worth most human cost, and, as demonstrated above, even governmental policies have undermined ethical behavior.

In fact, there is a national and international version of Better Off Ted playing at cinemas everywhere, namely global capitalism! In an era when big statism is globally unpopular, it has come to be widely accepted that private enterprise is the best way to build prosperity, and morality is not prominent in this story. The received wisdom, articulated recently by the International Monetary Fund's Christine Lagarde, for instance, is that economic growth is the necessary condition for the wellbeing of the world (Lagarde 2015; Naím 2015), let alone any individual jurisdiction within it (fed, of course, by our own acquisitive instincts that must be maintained to consume the growth). With few exceptions (e.g., North Korea, Cuba, Venezuela), governments are reliant on 
private enterprise to do the job and make happen the wealth "creation" political leaders promise their electorates and upon which their longevity in office is dependent. Governments talk up any statistic that paints a picture of lower unemployment or the creation of "new" jobs and take immediate credit for these signs of improving economic health, achieved by policy settings that produce the right conditions for such employment to grow. By any quantitative yardstick this nearly always sounds good. So does the assertion that global capitalism with free trade, coupled with labor and capital mobility, lifts millions of people out of poverty in "underdeveloped" parts of the world. The problem is that the qualitative side of the ledger is rarely examined. The comic observation that one's neighborhood has "five new jobs in it and you have three of them" or jobs are part-time and/or offer little pay draws ironic attention to the fact that behind the glowing numbers lie profound personal, social, and cultural consequences that have ethical significance about the way we lead our lives. Most importantly, how far can a government go to protect the so-called golden goose when dealing with companies that may threaten to withdraw jobs and investment as a bargaining tool to obtain favorable tax and regulatory conditions?

For instance, in the state of Tasmania there is recent history of a major company getting too close to successive state governments before ultimately imploding (see Beresford 2015). This fascinating, disturbing, and sad morality tale of how a forestry company tried to build a pulp mill and in the process silenced environmental concerns about a cheap bulk product coming from old growth forest logging is an example of how nurturing the golden goose can damage the community and its institutions. How far do we go to generate jobs, what is the quality of those jobs, and what are the social and environmental impacts? It is true that both sides of this logging war have acted badly at times, including some more extreme environmentalists (van Tiggelen 2014). However, when we live in polities with electorates that accept the generation of "new jobs" as an unchallenged inherent good, alarm bells should ring. Do we look at the tragedies of Bangladeshi sweatshops or the factory farming conditions in the Chinese phone and computer industries (Bilton and O'Brien 2015) when there is glowing talk of "lifting" people out of poverty? Do we examine the rural decimation that results from young people relocating to already overloaded cities for a new kind of "prosperous" life far away from family and community? Do we even dare question the pressures of "workforce participation" and the lack of economic choice for families where parents laboring as much as possible in the "paid" workforce is now an unquestioned "good" regardless of job quality, career prospects, personal circumstances, and family wishes or needs?

Governments are prepared to turn cartwheels in the old developed countries to stop companies from moving jobs "offshore" to places where there is cheaper labor. The prospect of high levels of long-term unemployment in old industrial communities is devastating. However, some would say that this is just a process of global wealth redistribution through the means of modern capitalism as a sort of latter-day Robin Hood, where some of the cake is taken from places that have a lot and given to those that have none. In other words, the developed world suffers unemployment and the developing world obtains new jobs - although low-paid and with poor conditions that some claim are "better than nothing." The ethics of this trade-off are not straightforward, and at least on a utilitarian analysis, it might be best to ask workers whether they feel better off.

It is difficult to argue that the old totalitarian or staterun economic models have anything to commend them or that we should resurrect them from the dustbin of history (see, e.g., Yergin and Stanislaw 2002). Few would want to see less small business, fewer entrepreneurs, and more government interference in things the government is hopeless at; or more taxes; or, for that matter, excessively obstructive labor unions that impede healthy business growth. But people also might be less desirous of unsafe and unfair societies; public institutions that haven't the means to protect them against economic, environmental, and medical disasters; and ever-growing corporations that can treat elected officials as vassals and workers as, albeit consenting (in a Marxist sense), slaves (Bales 2012). Effective global recognition of the need for moral limits to capitalism is an ongoing challenge that seems to take a backseat in a "winner takes it all," "who dares wins," "whatever it takes" approach to business that prevails nearly everywhere and that governments seem only too happy to buy into. Executives and boards and the organizations they govern need to understandand incorporate in their mission statements and business plans - that they have a duty not just to their shareholders but also to their workers and the larger societies and world in which we all live. Only when these are given equal moral force can capitalism and "free 
enterprise" free millions from the new moral slavery it fosters in prosperous and developing places alike.

The question remains: Can institutions, governments, and companies be trustworthy, particularly within a modern global economy that defines success in narrow ways? Do they have a duty to be socially responsible? It would seem that we should expect both trustworthiness and responsibility as givens, particularly since corporations and other organizations often are afforded the same legal protections as people (e.g., Santa Clara County v. Southern Pacific Railroad Company, 118 U.S. 394 [1886]; Burwell v. Hobby Lobby, 573 U.S. __ [2014]; Wheaton College v. Burwell, 573 U.S.___ [2014]). But they don't seem to be held to the same obligations. For instance, as Thom Hartmann discusses in his book Unequal Protection: How Corporations Became "People"-and How You Can Fight Back (2010), Pfizer pleaded guilty to "multiple criminal felonies" in September 2009 for "marketing drugs in a way that may well have led to the deaths of people and definitely led physicians to prescribe and patients to use pharmaceuticals in ways that were not intended" (Hartmann 2010, 1; see also Sharp 2012). But because

Pfizer is a corporation - a legal abstraction, really_it couldn't go to jail like fraudster Bernie Madoff or killer John Dillinger; instead it paid a $\$ 1.2$ billion "criminal" fine to the U.S. government - the biggest in history - as well as an additional $\$ 1$ billion in civil penalties. The total settlement was more than $\$ 2.3$ billion - another record. None of its executives, decision-makers, stockholders/owners, or employees saw even five minutes of the inside of a police station or jail cell (Hartmann 2010, 1).

Sadly, there are too many examples illustrating this peculiar predicament, and it is hard to capture a sense of the consequences an abjection of trustworthiness and social responsibility has on health and well-being using an anecdote here and there. And although Pfizer (and others in similar positions) paid fines, was this an appropriate and sufficient punishment? What kind of effects has it had on actual practice?

While "sometimes in spite of [an organization's] best efforts [...] a bad product does get through" (Better Off Ted 2009f, "Trust and Consequence," episode 110), it is wrong and rather illogical to organize a system around short-term consequences and shortsighted returns. By doing so, in essence we have all agreed that "profit" trumps "person" most every time. In Better Off Ted, Veronica makes this clear when she and Veridian want to pay off Linda to take the fall for a harmful product she warned them about during testing but they released anyway. Ground into despondency by the company's practices, Linda concedes, although Ted objects.

VERONICA Let it go. Let her take the deal and make some money.

TED Don't you see what's happening? We are taking the only person here who has never compromised her ideals and, and turning her into an ideal compromiser. And I don't mean an ideal compromiser, one who all the other compromisers look up to.

VERONICA I understand context, Ted.

TED She was our conscience. So now what are we going to do?

VERONICA [sarcastically] Gosh, you're right. How will we ever make the Fortune 500 list of the most moral companies? Oh, wait. They don't have that (Better Off Ted 2009f, "Trust and Consequence," episode 110, emphasis original).

Nor does it really exist in science and medicine, either. The conversation Ted has with scientists Phil and Lemwhen a serendipitous side effect of a failed wrinkle cream is the growth of new hair - perhaps has an uncomfortable ring of truth with regard to how participant protections are viewed in the midst of potential discovery:

PHIL I'll draw up the proposal and get the paperwork in. If all goes well, we can start work on this by next fall.

TED Next fall? No, we can't wait that long. We gotta keep movin'. [...]

[Days later when Lem and Phil have atomized the cream into an aerosol.]

TED This is incredible. I want to start testing.

PHIL But we are testing [pointingto potatoes with various stages of hair growth]. See, testers [indicating he and Lem], testees [the potatoes]. Testing. [...]

TED I mean human testing.

LEM Ted, we can't test it on humans. There's a whole protocol we have to follow. Uh, first we have to 
test it on a rat, then a bat, then for some reason a hat.

PHIL I think that started as a typo.

LEM Then a cat.

TED Forget about it, guys. I'm telling you, I want you to speed this along.

LEM No

TED [unhappily surprised] What?

PHIL [stunned] He said, "No." At least I think that's what he said.There's a lot of blood rushing through my ears right now.

LEM We are not mad scientists, Ted, regardless of what our bowling shirts might say.

TED Guys, when I ask you to do something, I expect you to do it.

PHIL [hesitantly] Apparently, we're standing our ground.

TED Fine. Then I'm going to get you bowling shirts that say "boss-disappointing, protocol-loving, un-legendary scientists" (Better Off Ted 2009b, "Father, Can You Hair Me?" episode 111, emphasis original).

Again, the language used here underscores a notion that one can't be both "legendary" and ethical. But why not? Maybe there should be a list of the most moral companies and awards for the most moral scientific research and health care practice. Maybe we need to redefine "success" to incorporate real understandings of right and wrong and take a wider and longer view.

Otherwise, we are left with Veridian approaches that are placed outside of ethics and are disconnected from social responsibilities, with individuals and vulnerable populations bearing the brunt of "externalities."

And no matter how often we exasperatedly profess “[t]hat's not normal," like Lem does when Veridian places the toilet paper holders in the company bathrooms beyond arm's length (in an attempt to save money by engineering inconvenience so employees use less) and Phil suggests he remove the roll from the holder and carry it to the toilet with him every time, Phil's response is sobering.

"It becomes normal, if you keep doing it," he says despondently. "Everything does" (Better Off Ted 2009e, "Pilot," episode 101).

The risks of maintaining the status quo really can't be better summed up than that.

\section{References}

Amzat, J. 2015. The question of autonomy in maternal health in Africa: A rights-based consideration. Journal of Bioethical Inquiry 12(2). doi:10.1007/s11673-015-9607-y.

Bales, K. 2012. Disposable people: New slavery in the global economy, revised ed. Berkeley and Los Angeles: University of California Press.

Bélisle-Pipon, J.-C., and B. Williams-Jones. 2015. Drug familiarization and therapeutic misconception via direct-to-consumer information. Journal of Bioethical Inquiry 12(2). doi:10.1007/s11673-015-9634-8.

Bending, Z.J. 2015. Reconceptualising the doctor-patient relationship: Recognising the role of trust in contemporary health care. Journal of Bioethical Inquiry 12(2). doi:10.1007/ s11673-014-9570-z.

Beresford, Q. 2015. The rise and fall of Gunns Ltd. Sydney: NewSouth Books.

Better Off Ted. 2009a. Bioshuffle. Written by Michael A. Ross, directed by Michael Fresco. ABC, June 30.

Better Off Ted. 2009b. Father, can you hair me? Written by Michael Glouberman, directed by Michael Fresco. ABC, July 21.

Better Off Ted. 2009c. Heroes. Written by Victor Fresco, directed by Michael Fresco. ABC, March 25.

Better Off Ted. 2009d. Jabberwocky. Written by Michael A. Ross, directed by Michael Fresco. ABC, August 11.

Better Off Ted. 2009e. Pilot. Written by Victor Fresco, directed by Michael Fresco. ABC, March 18.

Better Off Ted. 2009f. Trust and Consequence. Written by Mike Teverbaugh, directed by Lee Shallat-Chemel. ABC, July 14.

Bilton, R., and K. O'Brien. 2015. Apple's broken promises. Four Corners, March 2. http:/www.abc.net.au/4corners/stories/ 2015/03/02/4187424.htm.

Bismark, M., and J. Morris. 2014. The legacy of the Cartwright Report: "Lest it happen again." Journal of Bioethical Inquiry 11(4): 425-429.

Brown, B., J. Kinsler, M.O. Folayan, K. Allen, and C.F. Cáceres, 2014. Post-approval monitoring and oversight of U.S.-initiated human subjects research in resource-constrained countries. Journal of Bioethical Inquiry 11(2): 119-123.

Browne, T.K. 2015. Is premenstrual dysphoric disorder really a disorder? Journal of Bioethical Inquiry 12(2). doi:10.1007/ s11673-014-9567-7.

Carpenter, Z. 2014. Fast-food CEOs make 1,200 times as much as one of their workers - and they want to keep it that way. The Nation, April 24. http://www.thenation.com/blog/179525/mostunequal-industry-america-also-one-fighting-minimum-wage.

Cook, R.J. 2015. Off-label drug use as a consent and health regulation issue in New Zealand. Journal of Bioethical Inquiry 12(2). doi:10.1007/s11673-014-9568-6.

Craig, S.C., and P.S. Rippere. 2014. Political trust and negative campaigns: Two tests of the figure-ground hypothesis. Politics \& Policy 42(5): 693-743.

Dowling, C.M., and A. Wichowsky. 2015. Attacks without consequence? Candidates, parties, groups, and the changing face of negative advertising. American Journal of Political Science 59(1): 19-36.

Elpern, E.H., B. Covert, and R. Kleinpell. 2005. Moral distress of staff nurses in a medical intensive care unit. American Journal of Critical Care 14(6): 523-530. 
Faunce, T., R. Townsend, and A. McEwan. 2010. The Vioxx pharmaceutical scandal: Peterson v Merke Sharpe \& Dohme (Aust) Pty Ltd (2010) 184 FCR 1. Journal of Law and Medicine 18(1): 38-49.

Friess, S., and M. Keller. 2014. Follow the money: Big donors leave big mark on 2014 elections: Thanks to loopholes, workarounds and momentous court rulings, outside money is playing a bigger role than ever. Al Jazeera, November 1 . http://america.aljazeera.com/multimedia/2014/11/bigelection-donors2014.html.

Galarneau, C. 2015. Health care sharing ministries and their exemption from the individual mandate of the Affordable Care Act. Journal of Bioethical Inquiry 12(2). doi:10.1007/ s11673-015-9610-3.

Gamble, V.N. 1997. Under the shadow of Tuskegee: African Americans and health care. American Journal of Public Health 87(11): 1773-1778.

Haire, B. 2015. It's time: The case for PrEP as an active comparator in HIV biomedical prevention trials. Journal of Bioethical Inquiry 12(2). doi:10.1007/s11673-014-9565-9.

Hallman, B. 2014. Whistleblowers, beware: Most claims end in disappointment, despair. The Huffington Post, June 4. http:// www.huffingtonpost.com/2012/06/04/whistleblower-lawfalse-claims-act-awards-james-holzrichter n 1563783.html.

Harkness, J., S.E. Lederer, and D. Wikler. 2001. Laying ethical foundations for clinical research. Bulletin of the World Health Organization 79(4): 365-372.

Harris, P. 2013. Conservative lobby group behind push to lower minimum wage, report says: Politicians backed by conservative group Alec have introduced 67 laws in 25 states aimed at reducing minimum wage levels. The Guardian, March 6. http://www.theguardian.com/politics/2013/mar/06/alecminimum-wage-report.

Hartmann, T. 2010. Unequal protection: How corporations became "people"- and how you can fight back, 2nd ed. San Francisco: Berrett-Koehler Publishers, Inc.

Heyes, C.J., and A. Thachuk. 2015. Queering know-how: Clinical skill acquisition as ethical practice. Journal of Bioethical Inquiry 12(2). doi:10.1007/s11673-014-9566-8.

Hiltzik, M. 2014. BP offers a lesson in how to sugarcoat an environmental disaster. Los Angeles Times, October 22. http://www.latimes.com/business/hiltzik/la-fi-mh-bp-offersa-lesson-20141022-column.html.

Jameton, A. 1984. Nursing practice: The ethical issues. Englewood Cliffs, NJ: Prentice-Hall.

Jameton, A. 2013. A reflection of moral distress in nursing together with a current application of the concept. Journal of Bioethical Inquiry 10(3): 297-308.

Kleinsman, J., and S. Buckley. 2015. Facebook study: A little bit unethical but worth it? Journal of Bioethical Inquiry 12(2). doi:10.1007/s11673-015-9621-0.

Kopp, O. 2006 Historical review of unethical experimentation in humans. In Ethics in the professions: Proceedings of the 8th annual Utah Valley State College conference by the faculty, edited by R. McDonald and D. Yells, 2-11. Orem: Utah Valley State College Center for the Study of Ethics.

Kristof, N.D. 1995. Unmasking horror-a special report: Japan confronting gruesome war atrocity. The New York Times, March 17. http://www.nytimes.com/1995/03/17/world/ unmasking-horror-a-special-report-japan-confrontinggruesome-war-atrocity.html.
Kumar, N. 2014. Controversial vaccine studies: Why is Bill \& Melinda Gates Foundation under fire from critics in India? The Economic Times, August 31. http://articles.economictimes. indiatimes.com/2014-08-31/news/53413161_1 hpv-vaccinecervarix-human-papilloma-virus.

Lagarde, C. 2015. Lift growth today, tomorrow, together. Atlantic Council, April 9. http://www.imf.org/external/np/speeches/ 2015/040915.htm.

Lombardo, P. 2008. Three generations, no imbeciles: Eugenics, the Supreme Court, and Buck v. Bell. Baltimore: The Johns Hopkins University Press.

Manninen, B.A. 2015. Mutual scorn within the abortion debate: Some parallels with race relations. Journal of Bioethical Inquiry 12(2). doi:10.1007/s11673-015-9606-z.

McGrath, P., N. Rawson, and L. Adidi. 2015. Diagnosis and treatment for vulvar cancer for indigenous women from East Arnhem Land, Northern Territory: Bioethical reflections. Journal of Bioethical Inquiry 12(2). doi:10.1007/ s11673-014-9549-9.

McLennan, S.R., M. Diebold, L.E. Rich, and B.S. Elger. 2014. Nurses' perspectives regarding the disclosure of errors to patients: A qualitative study. International Journal of Nursing Studies. Epub ahead of print October 13, doi:10. 1016/j.ijnurstu.2014.10.001.

McNicoll, A. 2013. How Google's Calico aims to fight aging and "solve death." CNN, October 3. http://www.cnn.com/2013/ 10/03/tech/innovation/google-calico-aging-death/.

Naím, M. 2015. The Lagarde consensus: IMF chief Christine Lagarde on the global economy's "new mediocre" - and why women are better leaders than men. The Atlantic, April 12. http://www.theatlantic.com/international/ archive/2015/04/the-christine-lagarde-consensus-imf/ $390309 /$.

Patton, L. 2012. McDonald's \$8.25 man and \$8.75 million CEO shows pay gap. Bloomberg Business, December 12. http:// www.bloomberg.com/news/articles/2012-12-12/mcdonalds-8-25-man-and-8-75-million-ceo-shows-pay-gap.

Pendry, P.S. 2007. Moral distress: Recognizing it to retain nurses. Nursing Economics 25(4): 217-221.

Perechocky, A. 2014. Los torturadores medicos: Medical collusion with human rights abuses in Argentina, 1976-1983. Journal of Bioethical Inquiry 11(4): 539-551.

Peter, E., and J. Liaschenko. 2013. Moral distress reexamined: A feminist interpretation of nurses' identities, relationships, and responsibilities. Journal of Bioethical Inquiry 10(3): 337345 .

Plumridge, H., and L. Burkitt. 2014. GlaxoSmithKline found guilty of bribery in China: U.K. drug maker handed largest ever corporate fine in China. The Wall Street Journal, September 19. http://www.wsj.com/articles/ glaxosmithkline-found-guilty-of-bribery-in-china1411114817.

Reverby, S.M. 2012. Ethical failures and history lessons: The U.S. Public Health Service research studies in Tuskegee and Guatemala. Public Health Reviews 34(1): 1-18. http:// www.publichealthreviews.eu/upload/pdf_files/11/00 Reverby.pdf.

Sharp, K. 2012. Blood medicine: Blowing the whistle on one of the deadliest prescription drugs ever. New York: Plume.

Skloot, R. 2010. The immortal life of Henrietta Lacks. New York: Crown. 
Slegers, C., D. Zion, D. Glass, et al. 2015. Why do people participate in epidemiological research? Journal of Bioethical Inquiry 12(2). doi:10.1007/s11673-015-9611-2.

Smith, D. 2011. Pfizer pays out to Nigerian families of meningitis drug trial victims: Pfizer pays compensation to families of four children after 15-year legal battle over controversial drug trial in state of Kano. The Guardian, August 12. http://www. theguardian.com/world/2011/aug/11/pfizer-nigeriameningitis-drug-compensation.

Spielman, B. 2015. Nonconsensual clinical trials: A foreseeable risk of offshoring under global corporatism. Journal of Bioethical Inquiry 12(1): 101-106.

U.S. Department of Health and Human Services. No date. Fact sheet on the 1946-1948 U.S. Public Health Service sexually transmitted diseases (STD) inoculation study. http://www. hhs.gov/1946inoculationstudy/factsheet.html. Accessed March 20, 2015.

van Tiggelen, J. 2014. The destruction of the Triabunna mill and the fall of Tasmania's woodchip industry: How the end of Gunns cleared a new path for Tasmania. The Monthly, July 2014. https://www.themonthly.com.au/issue/2014/july/ 1404136800/john-van-tiggelen/destruction-triabunna-milland-fall-tasmanias-woodchip-.

Yergin, D., and J. Stanislaw. 2002. The commanding heights: The battle for the world economy. New York: Touchstone.

Zuzelo, P.R. 2007. Exploring the moral distress of registered nurses. Nursing Ethics 14(3): 344-359. 